\title{
THE TYPOLOGY AND ORIGIN OF ACCENTUAL VERSE
}

\author{
Martin J. Duffell
}

$\mathrm{M}$

ANy of the earliest surviving verse texts in the languages of the Iberian Peninsula are syllabically irregular, but show clear signs of accentual regulation (see Cano 1931, Henríquez Ureña 1933, and Duffell 1999b), and Rudolf Baehr argued that accentual verse probably predated syllabic in all the Romance languages (1973: 177). There are certainly a number of early poems in vulgar Latin, French, Italian, Spanish, or Portuguese that are more regular accentually than syllabica1 ly (see Du Méril 1843, Hills 1925, Hall 1965, Purzinsky 1965, Bayo 1999, Duffell 2002, and Parkinson in press). Perhaps this is not surprising, since the Romance languages of Western Europe are direct descendants of Latin spoken by Germans, and early Germanic verse was accentual. For more than a century the structure of Germanic accentual verse has been the subject of extensive research and debate, to which recent advances in linguistics have added important new insights. Comparative metrists seeking an explanation of the earliest syllabically irregular Romance verse texts can benefit from this progress, and the present article offers a synopsis of the current state of Old Germanic metrics. This will be preceded by an analysis of the rhythms that are found in verse, and will conclude with a critique of modern hypotheses regarding the relationship between different types of metre in various Indo-European languages.

\section{Rhythm, Language, and Metre}

Rhythm is produced when a series of events occurs at what is perceived by the human ear as regular intervals, and there 
are at least three classes of rhythm that can occur in verse. ${ }^{1} \mathrm{~A}$ simple primary rhythm is produced by a series of identical events occurring at equal intervals; Chatman represents it graphically by asterisks equally spaced: ******** (1965: 20). A simple secondary rhythm occurs when identical events occur at differentiated intervals, thus: $* * * * * * * *$. A complex secondary rhythm occurs when two different types of event occur in combination, and it can be represented by asterisks and ampersands: $* \& * \& * \& * \&$. All three of these classes of rhythm can be found in European verse; thus, for example, two types of simple primary rhythm typify French syllabic verse: firstly, each line comprises a series of events called syllables, and their equivalence is emphasized by being delivered in such a way that equal time is allotted to each (syllable-timing). But passages of French verse also have another simple primary rhythm, because a special type of syllable appears in the final position of each line, a syllable that is made salient by combining phrasal stress with rhyme (see Cornulier 1995: 111-13). Both these simple primary rhythms can easily be reproduced in any other language with syllable-timing and phrasal stress.

The other Romance languages, however, are like Germanic ones in also having word stress, which enables stresses rather than syllables to become the rhythmic events that poets organize and audiences perceive. ${ }^{2}$ The rhythms that stresses produce tend

\footnotetext{
1 The human ear perceives intervals as equal providing there is no more than 14 per cent variation in their objective length. This limitation also applies to stressand syllable-timing, where 'equal' means 'perceptibly equal', rather than equal as measured by laboratory instruments (Chatman 1965: 111-13).

2 Stressed syllables combine greater duration and volume with a change in fundamental frequency (pitch) in both Germanic languages (Fry 1958) and Romance (Quilis 1971). Word stress, which seems to have been relatively weak even in Old French, has disappeared from the modern language, making phrasal stress more salient. The strong syllables of French words (those with lexical accent) are stressed in delivery only when they are phrase-final. In languages with word stress it is not a zero-sum property but a continuum (the syllables in an utterance are stressed to different degrees), and by no means all stressed syllables are relevant to versification. The relative stress principle, that the stress contrasts between adjacent syllables are the only ones relevant to metre, was first argued by Otto Jespersen in a paper published in 1900 (Preminger \& Brogan 1993: 1019-20) and was restated by Liberman \& Prince 1977.
} 
to be secondary ones, because either the varying number of other syllables makes the intervals between stresses unequal, or those other syllables themselves become a second type of event. Modern Germanic languages are not syllable-timed; instead the intervals between stresses tend be equalized in delivery, a phenomenon termed stress-timing or accentual isochrony (see Giegerich 1980 and 1985, Roach 1982, and Toledo 1988). Their verse therefore has a complex secondary rhythm, often described by the musical terms beats (prominent syllables) and offbeats (what lies between them; see Attridge 1982: 160). But stress-timing may have been a weaker tendency in older Germanic languages, because their verse has a simple secondary rhythm, one that groups stresses in pairs like the second series of asterisks above and allows considerable variance in the intervals between them. Some Romance languages have a tendency towards syllabletiming like French, some are stress-timed like modern Peninsular Portuguese, and others are ambivalent like Italian and Spanish (Toledo 1988). But, although all the Romance languages except French have word stress, most of their poets have not used it to produce regular secondary rhythms in their verse. The reasons for this are partly aesthetic (poets have preferred to employ word stress in the interests of variety rather than regularity) and partly sociological (the pressures of peer-group practice and French influence), but a number of examples of stress-syllabic verse in Spanish show that there is no inherent linguistic reason why stress should not be employed this way in Romance verse. ${ }^{3}$

\section{Old Germanic Verse}

It seems likely that any early-medieval Romance metrics based on accent and secondary rhythms would have shared some of the characteristics of Germanic verse in the same period, and

${ }^{3}$ Spanish poets who have composed stress-syllabic verse include Juan de Mena (b. 1411, d. 1456), Miguel de Cervantes (b. 1547, d.1616), and Rubén Darío (b. 1867, d. 1916); see Duffell 1999a: 64-78, and Domínguez Caparrós 1999: 45-66 and 2002: 79-85. 
a number of Germanic texts have survived composed between the ninth and the eleventh centuries AD, or perhaps earlier. They include the Old German Ludwigsleid (Braune \& Helme 1928), the Old Icelandic Edda (Dronke 1969), and many Old English poems (Hamer 1970). The syllabic irregularity and accentual regularity of such texts can be seen from the following lines (96-99) from the Old English Battle of Maldon (Scragg 1991), probably composed fairly soon after 991 when the battle was fought:

(49) Wo-den a wæl-wul-fas for wæ-te-re ne mur-non

(50) Wi-cin-ga we-rod

(51) O-fer scir wæ-ter

(52) Lid-men to lan-de

west o-fer Pan-tan

scyl-de we-gon

lin-de bæ-ron

('Wolves of war, unmindful of ocean,

The Viking horde surged west over Pante,

Carrying their shields over shining water,

Seafarers, bearing to land the linden; ${ }^{4}$ my translation.)

These lines contain an irregular number of syllables (between 8 and 13) and their most obvious regularity is in the number of prominent syllables: there are four strong stresses in each line, two in each half-verse. ${ }^{5}$ One nineteenth-century writer described this metre as a line in which stressed syllables $(2+2)$ are numerically regulated (Wackernagel 1879), but unstressed ones are not. There is, however, much more to this verse design than the number of strong positions and the prominence type stress. ${ }^{6}$ First of all, of the four strongly stressed syllables in the

${ }^{4}$ linden is the wood from which their shields were made.

${ }^{5}$ In my examples I employ the following scansion aids: (1) extra space is left between words, (2), syllables within words are separated by hyphens, (3) primary stress in polysyllabic words is shown by bold typeface, and (3) stressed monosyllables are underlined.

6 In this article I borrow the terminology of Jakobson 1960 and Hanson \& Kiparsky 1996. A verse design is the abstraction (metre) that we infer from actual lines (verse instances), and that design can be divided into template, or pattern, and a set of correspondence rules governing the linguistic material that may represent that pattern in verse instances. A template is characterized by position number and 
line, the first three are linked and emphasized by alliteration; the final stress, being the weakest in a left-strong line, lacks it. The alliteration in the passage quoted confirms the intuitive analysis that stress, not syllable strength, is the prominence type: the stressed monosyllables 'west' and 'scir' alliterate, but the strong syllable of the grammatical word 'ofer' does not.

Although most modern analyses of this metre accept that the verse design stipulates four strong stresses, they disagree with the idea that the material between them (the content of weak positions) is unregulated. Many different analyses of Old Germanic verse design (often referred to as accentual metre) have been offered, almost all of them based on the same text, Beowulf (Wrenn \& Bolton 1988). ${ }^{7}$ This, the most famous poem in the metre, may have been composed as early as the beginning of the ninth century, but we know it from a single manuscript in a language that seems to date from the end of the tenth (see Wrenn \& Bolton 1988: 9-13). Stockwell \& Minkova 1997 give an admirable synopsis of the modern debate on the metre of Beowulf, and I have drawn heavily on their work in the sections below. I shall first consider the two most widely held modern theories of Germanic metre and then examine two recent linguistic accounts of it. Finally I shall attempt to set the Old Germanic accentual mode of versifying in the historical context of other modes.

\section{Musical Theories}

Anumber of modern scholars have proposed that the numerical regulation in Beowulf was that of music (now lost) to which the text was set. Musical rhythm is the product of units (bars) each

orientation (whether positions alternate weak/strong or strong/weak) and correspondence rules govern position size (the maximum amount of linguistic material a position may contain), prominence site (whether weak positions, or strong, or both are constrained), and prominence type (the property of language (e.g. stress) that is constrained from appearing in the prominence site).

7 The relatively minor differences in verse design between Beowulf and the Battle of Maldon are discussed by Russom 1998: 157. 
containing material (notes) of the same total duration. These equal units are marked by beats, which always coincide with the opening note in each bar, and introductory notes before the beat of the first bar are regarded as anacrusis, or strikingup notes, and do not contribute to the rhythm (ABRSM 1958: 18). Any verse design can be described in musical terms, even a right-strong one, because the contents of its opening weak position can be labelled anacrusis. But a musical analysis of leftstrong Germanic metres has seemed particularly appropriate to many writers; for example, Heusler 1891, Pope 1942 \& 1966, and Creed 1966 \& 1990. A musical analysis enables metrists to regularize the extreme syllabic irregularity of this metre by inserting rests where there are too few syllables, and reducing the length of the note allotted to each where there are too many. The problem with such musical scansion is that we don't know how this verse was delivered, whether it was sung, or chanted, or recited.

Modern experience of oral epic delivery is confined almost entirely to the 'singing of tales' in Serbo-Croat (Lord 1960), and specialists in English verse have mostly been critical of any attempt to extrapolate these findings to the ancient Germanic tradition (see, for example, Campbell 1962). Traditional SerboCroat oral verse is quite unlike Old Germanic in one most important respect: the former is syllabically regular (lines have 9F syllables) and thus fits the isochrony of music extremely well. ${ }^{8}$ Germanic epic verse, on the other hand, is extremely irregular in syllable count; while it can be sung in the manner of Gregorian chant (that is, not isochronously), this is not the type of musical scansion that has usually been proposed. ${ }^{9}$ Stockwell \& Minkova rightly dismiss hypotheses of Beowulf's 'performance' as 'hazardous' (1997: 59). The one element of musical scansion that

${ }^{8}$ In describing line length in this article I shall adopt the French convention of using an arabic numeral for the number of syllable to the final stress followed by the suffix M (for masculine) or F (feminine).

9 Luecke 1978 proposes such a setting, which results in something far from isochrony. Cable 1974: 94-110 also discusses musical performance without regard to isochrony. 
most metrists find useful, however, is the concept of anacrusis. In many type of verse syllables before the first stress seem to be optional; they are allowed but not demanded by the verse design. Indeed, they may be termed extramusical in the same way that syllables after the final stress in the line are termed extrametrical, the two categories combining to produce boundary indifference..$^{10}$ On the whole, however, our uncertainties about delivery have made another, non-musical, method of analysis the prevailing orthodoxy of Old English metrics, the reference theory.

\section{Reference Theory}

Sievers 1885 first argued that the verse design of Beowulf allows certain configurations of stressed and unstressed syllables, but not others, and he identified five permissible types (subdivided by subsequent writers into six). This hypothesis and its many subsequent ramifications are known as reference theory. Stockwell \& Minkova illustrate the permissible structures by alliterating Modern English phrases and by half-verses of Beowulf, using '!' to describe a void position, as follows (1997: 69): ${ }^{11}$

10 The most obvious example of boundary indifference is that any syllables after the final stress in lines of Romance verse are not included in the syllable count. Some Spanish metres are also indifferent to the number of syllables before the first stress in the line (see Duffell 1999a: 68). Note also that in the analyses of Navarro 1974 only the syllables from one stress to the next are included in the rhythmic unit and syllables before the first such unit and after the last are classified as enlacing syllables.

11 The conventional analysis of English verse groups syllables into feet that contain contrasts between their weak (w) and strong (s) elements. The term foot has been retained by modern linguistics metrists to describe the weak/strong contrasts they find in both verse and language itself; see, for example, Liberman \& Prince 1977, Hogg \& McCully 1987, Hayes 1989 \& 1995, and Hanson \& Kiparsky 1996. 


\section{FIGURE 1}

\begin{tabular}{|c|c|c|c|c|}
\hline Type & English phrase & $\underline{\text { Scansion }}$ & Beowulf half-line & $\underline{\text { No }}$ \\
\hline A & Arnie's army & {$[\mathrm{s} \mathrm{w} / \mathrm{s} \mathrm{w}]$} & lāðan līges & $83 a$ \\
\hline B & in briny baths & {$[\mathrm{w} \mathrm{s} / \mathrm{w} \mathrm{s}]$} & $n \bar{e}$ lēof nē lāð & $511 \mathrm{a}$ \\
\hline $\mathrm{C}$ & by cost-cutting & {$[\mathrm{w} \mathrm{s} / \mathrm{s} \mathrm{w}]$} & beloren lēofum & $1073 a$ \\
\hline $\mathrm{D}_{1}$ & dumb dog-catcher & {$[\mathrm{s} ! / \mathrm{s} \mathrm{s} w]$} & flōd fceðmian & $3133 a$ \\
\hline $\mathrm{D}_{2}$ & dry daisy-chain & {$[\mathrm{s} ! / \mathrm{s} w \mathrm{~s}]$} & eall ēðelwyn & $2885 a$ \\
\hline $\mathrm{E}^{2}$ & egg-laying hen & {$[\mathrm{s} \mathrm{s} \mathrm{w} / \mathrm{s} !]$} & fèasceaftum men & $2285 a$ \\
\hline
\end{tabular}

All of these basic types have four actual syllables, and some 80 per cent of Beowulf's half-lines conform exactly to one of the six patterns. Most of the remainder can be explained with the aid of the concepts of anacrusis (the presence of one or more striking up syllables before the first metrically significant stress) and resolution (the equivalence of [s !] and [s w]). There then remain a small number of hypermetrical half-lines, which Sievers argued contain a third foot (1885: section 94), but which are open to other interpretations. Sievers's categorization is by no means perfect or complete, and subsequent writers added a great deal more detail. The most important advances were those of Bliss (1958 \& 1962), which subdivided the five Sievers types into 130 sub-types and provided an invaluable index of lines by type, and of Cable 1974 \& 1989, which offered the most convincing explanations to date of why the Sievers types were permissible and other configurations not.

Cable pointed out that the pattern [w s w / s w], Type A with single-syllable anacrusis, is one of the most common in Old English, yet the Beowulf poet avoided it, probably because it presents five stress contrasts rather than four (1974: 32-44). He also showed that the list of permissible types, like the phonology of the lexicon, excludes stress contours with two consecutive rises in relative stress (1974: 84-93). Cable thus identified important 
ways in which the rules governing the metre of the poem either differed from, or resembled those governing the language itself. The most important developments in the analysis of Old Germanic metrics in the last twenty years have built on this foundation of comparing metrical and linguistic norms. The two new theories I shall discuss here are both derived from generative linguistics: the first is a syntagmatic theory and the second is an application of optimality theory to the study of metrics. ${ }^{12}$

\section{The 'Word-Foot' in Old Germanic Verse}

Russom 1987 argues that the configurations of stress and syllable in Old English verse are closely related to the word structure of the language and coined the term word-foot to describe what he believes to be the basic constituent of the line. In Russom's analysis foot and word boundaries always coincide, and he argues that nine configurations of stress and syllable are found in Old English words and are permissible feet in its verse. I give them below, using his notation $(\mathrm{S}=$ primary stress, $\mathrm{s}=$ secondary stress, $\mathrm{x}=$ non-stress $)$ and his word examples (1987: 13):

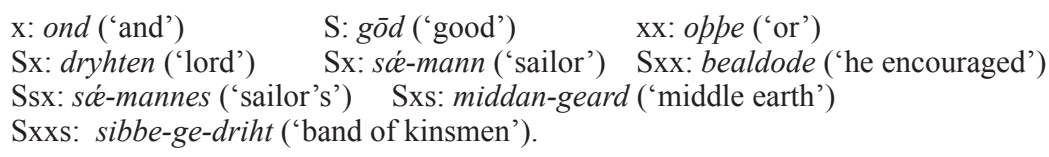

Some of these word-feet differ from the feet of traditional explanations of the metre: the two types of light foot that correspond to unstressed monosyllables $[\mathrm{x}]$ and disyllables $[\mathrm{x}$ $\mathrm{x}]$, and the tetrasyllabic foot [S x x s]. At the same time some traditional feet are excluded, most importantly the rising foot (iamb) that characterizes Sievers types B and C, but corresponds

12 The idea of basing metrical feet on words or syntagms was first proposed by Skeat 1898; this proposal was largely neglected until Macrí 1979 published his syntagmatic analysis of medieval Spanish verse. For a brief account of optimality theory see Archangeli \& Langendoen 1997. 
to no word in the language. Russom shows that all normal lines in Beowulf comprise two of his word-feet, in any of twentyfive possible combinations (1987: 20-23), and he explains hypermetric lines in term of 'overlapping feet', the expansion of a foot into a half-line on the model of compounding in the lexicon (1987: 59-63). Like earlier theories, Russom's recognizes anacrusis and allows extrametrical words to appear before either foot in a half-line (1987: 19-20). He notes that the word-feet found most often in verse are the most common structures of words in the lexicon (as we should expect, since he has made feet of words), and he describes less common structures as more complex (1987: 48-49).

Russom 1998 applies the word-foot theory to the fourbeat verse of three languages: Old English, Old Norse, and continental West Germanic. He concludes that differences in foot structure in the three verse traditions are linked to differences in the strength of stress (strongest in Old Norse, weakest in continental West Germanic) and offers an account of the evolution of four-beat verse in the three languages that relies heavily on linguistic determinism (1998: 206-15). Russom also uses his cross-linguistic comparison to demonstrate the inadequacies of reference theory, in particular Sievers's reliance on numerous ad-hoc principles in order to accommodate all the half-lines in his typology (1998: 195-204). Russom's theory is more than an alternative description of Old Germanic metre that uses different sub-units to account for line structure, because it offers a credible explanation of how the poems came to be composed. Reference theory provides a menu explanation of the process of composition: the poet had a number of variants to choose from in constructing the next line (five, according to Sievers, 130 according to Bliss); this seems an unlikely way for poets to work and is contra-indicated by modern experience. In contrast Russom's theory allows the poet to perform a simple repetitive act: to produce lines of four word-equivalents (linked by alliteration), using the inherent knowledge of possible word shapes that is part of his linguistic competence. 


\section{Optimality Theory: Constraints in Beowulf}

Getty 2002 analyses the metre of Beowulf using optimality theory, which replaces the idea of linguistic rules with that of a series of universal constraints. These are hierarchical, and the position of any given constraint in the hierarchy (which may change over time) determines its influence on linguistic output. ${ }^{13}$

Getty 2002: 10-15 offers an analysis of Beowulf's template based on parametric theory (Hanson \& Kiparsky 1996): position number: 8; orientation: left-strong; position size: one foot (or moraic trochee); prominence site: strong positions; prominence type: strength (the weak syllables of polysyllabic words are constrained from appearing in strong positions). This verse design can be recognized as the trochaic tetrameter of traditional metrics but, while Getty describes four trochees as the 'optimal' realization of the pattern, he argues that a number of other realizations are licensed by the poet's need to employ all the words in the Old English lexicon (the principle of fit). Thus non-optimal feet and non-optimal half-lines occur; Getty hypothesizes four types of foot, all of them left-strong (since any initial weak syllable is anacrusis), as follows (2002: 12):

a.

Foot

Foot

S

S W b.

Foot c.

Foot

d.

$\begin{array}{llll}\mathrm{S} W & \mathrm{~S} \text { W W }\end{array}$

In addition to sub-optimal feet, sub-optimal half-lines, with three feet instead of two, make up twenty per cent of total in the poem (2002: 13).

13 Hammond 1997 provides a concise introduction to the application of optimality theory in the area of prosody. Among his examples of constraints on English prosody is the following account of syncope (the loss of unstressed syllables, as when 'chocolate' become 'choc'late' in normal speech): constraint $1=$ FAITH $(\sigma s)$

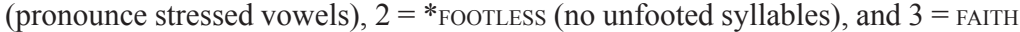
( $\sigma \mathrm{w})$ (pronounce unstressed vowels). Syncope occurs because the second of these constraints ranks more highly than the third (1997: 48-49). 
Getty's theory, which he supports with examples from Beowulf, can equally well be illustrated by the passage from the Battle of Maldon quoted in 3.1 above.

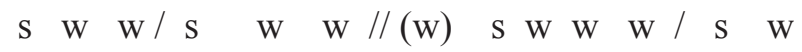

(49) Wo-den a wæl-wul-fas for wæ-te-re ne mur-non

$$
\text { s w w / s w // } \mathrm{s} \quad \mathrm{w} \text { w / } \mathrm{s} \quad \mathrm{w}
$$

(50) Wi-cin-ga we-rod west o-fer Pan-tan

(51) O-fer scir wæ-ter scyl-de we-gon $\mathrm{s} \quad \mathrm{W} \quad \mathrm{W} / \mathrm{s} \quad \mathrm{W} / / \mathrm{s} \quad \mathrm{w} / \mathrm{s} \quad \mathrm{W}$

(52) Lid-men to lan-de lin-de bæ-ron

Instance (49) thus comprises four feet: c, c / anacrusis, d , b; (50) comprises four feet: c, b c c, b; (51) comprises five feet: b, a, $\mathrm{b} / \mathrm{b}, \mathrm{b}$; and (52) comprises four feet: c, b / b, b. In this passage $10 / 17$ feet are optimal and 7/8 half-lines have the optimal two feet (the first of (51) has three). ${ }^{14}$

Having established his parameters Getty moves on to optimality theory and constructs his hierarchy of ranked constraints that will generate lines of the structure and frequency with which they appear in Beowulf. He lists forty-three constraints in all (2002: 311-13), and high on that list are (c) half lines occurring in the same line must be linked by alliteration, (d) the maximum size a metrical position is that of a phonological foot, and (e) stressed syllables are barred from occupying weak metrical positions. ${ }^{15}$ At the top of the list, however, are two that over-ride all others: (a) languages select metres in which their entire vocabularies are

${ }^{14}$ Getty argues that line-initial grammatical words like 'ofer' form (trochaic) metrical feet of their own (2002: 13); for a discussion of the metrical status of words of this type see Duffell 1999a: 27-29. Note that this left-strong interpretation of a sequence of syllables without lexical accent is supported by the 'core' theory of Indo-European accentuation: words not otherwise accented attract initial stress (Halle 1997: 276). The loss of (melodic) accent (on one of the last three syllables) in lexical words probably explains the initial stress that is a feature of a number of ancient and modern Indo-European languages.

15 Here I assume that the word 'unstressed' (Getty 2002: 311) is a typographical error. 
usable in the greatest variety of ways, and (b) metrical boundaries should be maximally distinct. The first of these elevates the principle of fit to a constraint: it is contentious in that it can be applied to all verse and licenses all exceptions to other metrical rules, as long as those exceptions constitute words. Nevertheless, Getty's book is a highly significant contribution to the debate on Old English metre, elegantly combining several important innovations in linguistics: parametric theory, the principle of fit, and optimality theory. Most importantly of all, as Getty 2002: 6 points out, this theory frees Old English verse from its isolation: it is not a metrical curiosity, but an early example of the same type of verse we find later in English.

\section{The Rhythmic Typology of Old Germanic Verse}

Reference theory, like the simplistic analysis of Wackernagel 1879 , would lead us to classify the rhythm Old English verse as a simple secondary rhythm: the events are the stresses (which also bear an alliterative pattern), and they occur in pairs of pairs; all else (whether the allowable configurations of stress and syllable are six or 130) is a source of variety, not of regularity. In contrast, Russom's theory and, even more clearly, Getty's theory imply that a complex secondary rhythm is present (as in modern English stress-syllabic verse), a series of trochees, contrasts between two different types of event, stress and nonstress. Both of these interpretations may be valid, because more than one type of rhythm may be present in the delivery of a text. As we have noted, Romance languages with word stress have successfully adopted French syllabic metres in such a way that the primary rhythms created by phrasal stress at the end of the line offer regularity, while the irregularly placed word stresses within it offer variety. ${ }^{16}$ This awareness of two types of rhythm

\footnotetext{
${ }^{16}$ Dorchain 1919: 22-23 points out that the human mind craves opposite effects: sécurité, which is provided in verse by conforming to the metre, and surprise, which is provided by deviating from it. This deviation is usually termed tension and almost all verse contains it (see Allen 1973: 111).
} 
in the same line has been labelled double audition. ${ }^{17}$

Beowulf's audience would have been most aware of the simple secondary rhythm of two plus two events (stresses), but they also may have recognized another more subtle rhythm, the complex rhythm of strong-weak contrasts. Certainly the poet was observing more rules than those that produce two-plustwo stresses. As modern analysis has shown, he consciously or subconsciously created a trochaic text, one that instinctively echoed the process of word formation in his language.

\section{The Evolution of Accentual Verse}

The hypothesis of Meillet 1923 that all Indo-European metres have evolved from syllabic originals has become the orthodoxy of European metrists (see West 1973: 161 and Gasparov 1996: 710). The explanation of syllabically irregular verse in this group of languages is attributed to syllable loss (by syncope and finalvowel deletion) in the languages concerned, which would have ensured that new pronunciations of old lines would destroy their regularity. The antiquity, and wide distribution of such irregular verse, however, should cause us to re-examine this hypothesis.

As I have noted, pre-literate verse antedates literate verse, and the folk verse (proverbs and nursery rhymes) of many European languages are not only syllabically irregular, they also contain accentual patterns (for Romance examples, see Milá y Fontanals 1893, Bayo 1999, Duffell 2002). The evidence for Meillet's hypothesis, on the other hand, comes from the written texts: the Old Iranian Avesta, the Sanskrit Rig Veda, and some Greek inscriptions, which, like Greek Aeolic metres, are all regular in syllable count. Although the oldest Indo-European verse text of all, the Hittite Song of Ullikummi, is irregular, it is dismissed as the product of Semitic influence by the supporters of Meillet's

${ }^{17}$ For an explanation of double audition in English see Lewis 1938 and in Spanish see Duffell 2000. 
hypothesis. ${ }^{18}$ They also discount as a later development the quantity contrasts that characterize the second half of the earliest Sanskrit lines and pervade all Greek ones. But the fact that most of the surviving ancient texts are syllabic proves only that ancient Indo-European peoples used this mode of versifying, not that it was the only mode, nor that all others must be derived from it.

That the texts that have survived are syllabic cannot be dissociated from the method of preservation: the oldest scripts in which the verse is written are open syllabaries, where one syllable equals on sign (Gaur 1984: 14-17). ${ }^{19}$ Such scripts make syllabic verse perfectly regular to the eye as well as the ear, and would give it a clear evolutionary advantage. Texts already syllabically regular would have gained aesthetic preference from the invention of writing and irregular ones could easily have been regularized (see Duffell 1999b: 166-67 and 2003: 115). The Avesta and Rig Veda, in particular, were products of a priesthood in possession of a revolutionary new technology, one which may have led to the selection of one of several existing types of metre, or even to the invention of modes of versifying that were previously unknown.

The oldest surviving Germanic line of verse, which dates from c. $400 \mathrm{AD}$, is an inscription on a horn in a language that was probably an early form of Old Norse. It is given in Russom 1998: 1, as follows (except that I have used $\check{r}$ to represent the sound between $z$ and $r$, for which Russom uses $R$ ):

(53) ekhlewagastiř : holtijař : horna : tawido :

('I Hlewagast, Holt's son, made this horn'; Russom's translation)

\footnotetext{
${ }^{18}$ West 1973: 182 attributes the phrase-based metre of the Hittite Song of Ullikummi (second millennium BC) to Semitic influence, but Semitic languages are not the only ones to employ the devices of division into cola, repetition, and verbal parallelism.

19 This contrasts with Egyptian hieroglyphs and Chinese ideograms, where one sign generally equals one word, and alphabets of the Semitic type, where one sign equals one consonant.
} 
This inscription, with its four strong stresses and alliterative pattern, is unmistakably in the same metre as Beowulf. Hlewagast's metrical intention is not thirteen syllables, but four words, as the colons and the inclusion of the pronoun 'ek' in the first word clearly show. ${ }^{20}$ This example of word-based metre, geographically distant from Semitic influence, suggests that at least one ancient Indo-European people employed a mode of versifying other than the syllabic. Since counting by ear up to four is easy, and to thirteen impossible (see Hurford 1987: 93-95 and Miller 1956: passim), it seems very likely that, when ancient Indo-European poets wanted lines of this length, they would have based them on word count. The alternative would have been to subdivide all the lines in the same place (for example, into 4: 3 : 3: 3 syllables, as in (53)). This alternative, which requires much greater effort, would have been attractive only once writing (in an open syllabary) had given it the advantage of visual regularity.

Old Germanic verse seems to have been based on words from its very beginning (hence the appropriateness of Russom's term, word-foot). Moreover, all the languages in which I have instanced accentual metres in this chapter are synthetic and highly inflected ones; for them syncope and schwa-loss lie in the future, and it is difficult to envisage that such lines once had additional syllables, which eroded to make them irregular. Bringing Old Germanic metre back into the mainstream of European historical metrics (Getty 2002: 6) has important repercussions: it brings strong evidence against Meillet's hypothesis that all Indo-European verse was originally syllabic and that other types evolved from it.

\section{Conclusion}

This brief survey of accentual metres and their origins shows that they are not an aberration of one language-group at one point of time, but a rhythmic possibility in most languages. Modern

20 The division into four units is that of the original inscription; the colons printed here were lines of four points on the horn itself. 
metrists have made their discipline a comparative one in which universals of versifying can be identified in the same way that linguistics has discovered universals of language itself. They have found no reason why versifiers should not have discovered the same rhythmic potential in the Romance languages as in the Germanic. Twenty-first century metrists can now return to the disputed examples of accentual verse in Romance armed with considerable new ammunition from the modern study of Old Germanic versification.

\section{Works Cited}

ABRSM, 1958. Rudiments and Theory of Music (London: Associated Board of the Royal Schools of Music).

ALLEN, W. SIDNEY, 1973. Accent and Rhythm: Prosodic Features of Latin and Greek: A Study in Theory and Reconstruction (Cambridge: Cambridge UP).

ARCHANGELI, DIANA, \& D. TERENCE LANGENDOEN, 1997. Optimality Theory: An Overview (Oxford: Blackwell).

ATTRIDGE, DEREK, 1982. The Rhythms of English Poetry, English Language Series, 14 (London: Longman).

BAEHR, RUDOLF, 1973. Manual de versificación española, trans. K. Wagner and F. López Estrada (Madrid: Gredos).

BAYO, JUAN CARLOS, 1999. 'La teoría del verso desde el punto de vista linguïstico (el sistema de versificación del Cantar de Mio Cid)', doctoral thesis, Univ. of Barcelona.

BLISS, ALAN J., 1958. The Metre of 'Beowulf' (Oxford: Blackwell). —, 1962. An Introduction to Old English Metre (Oxford: Blackwell).

BRAUNE, WILHELM, \& KARL HELME, 1928. Althochdeutsche Lesebuch (Halle: Niemayer).

CABLE, THOMAS M., 1974. The Meter and Melody of 'Beowulf' (Urbana: Univ. of Illinois Press).

- 1989. 'Old and Middle English Prosody: Transformations of the Model', in Hermeneutics and Medieval Culture, ed. Patrick J. Gallacher \& Helen Damico (Albany: SUNY Press), pp. 201-11.

CAMPBELL, ALISTAIR, 1962. Review of Lord 1960, Modern Language Review, 57: 75.

CANO, JUAN, 1931. 'La importancia relativa del acento y de la sílaba en la versificación española', Romanic Review, 22: 223-33.

CHATMAN, SEYMOUR, 1965. A Theory of Meter (The Hague: Mouton).

CORNULIER, BENOÎT DE, 1995. Art poëtique: notions et problèmes de métrique (Lyon: Presses Universitaires de Lyon).

CREED, ROBERT PAYSON, 1966. 'A New Approach to the Rhythm of Beowulf', Publications of the Modern Language Association of America, 81: 23-33. 
—, 1990. Reconstructing the Rhythm of 'Beowulf' (Columbia and London: Univ. of Missouri Press).

DOMÍNGUEZ CAPARRÓS, JOSÉ, 1999. Estudios de Métrica, Aula Abierta, 36128 (Madrid: Universidad de Educación a Distancia).

-, 2002. Métrica de Cervantes, Biblioteca de Estudios Cervantinos, 10 (Alcalá: Centro de Estudios Cervantinos).

DORCHAIN, AUGUSTE, 1919. L'Art des vers, $2^{\text {nd }}$ ed. revised (Paris: Garnier); $1^{\text {st }}$ ed. published in 1911.

DRONKE, URSULA, ed., \& tr., 1969. Edda, I, Heroic Poems (Oxford: Clarendon Press).

DU MÉRIL, EDÉLESTAND, 1843. Poésies populaires latines antérieures au douzième siècle (Paris: Brockhaus et Avenarius).

DUFFELL, MARTIN J., 1999a. Modern Metrical Theory and the 'Verso de arte mayor', Papers of the Medieval Hispanic Research Seminar, 10 (London: Queen Mary and Westfield College).

- 1999b. 'The Metric Cleansing of Hispanic Verse', Bulletin of Hispanic Studies (Liverpool), 76: 151-68.

- 2000. 'The Santillana Factor: The Development of Double Audition in Castilian', in Santillana: A Symposium, ed. Alan Deyermond, PMHRS, 28 (London: QMW), pp. 113-28.

-, 2002. 'Don Rodrigo and Sir Gawain: Family Likeness or Convergent Development?', in 'Mio Cid' Studies: 'Some Problems of Diplomatic' Fifty Years On, PMHRS, 42, (London: QMW), pp. 129-50.

—, 2003. 'French Symmetry, Germanic Rhythm, and Spanish Metre', in Chaucer and the Challenges of Medievalism: Studies in Honor of H. A. Kelly, ed. Donka Minkova \& Theresa Tinkle (Bern: Peter Lang Verlag), pp. 105-27.

FRY, DENNIS, 1958. 'Experiments in the Perception of Stress', Language and Speech, 1: 126-52.

GASPAROV, M. L., 1996. A History of European Versification, tr. G. S. Smith \& Marina Tarlinskaja, ed. G. S. Smith with L. Holford-Strevens (Oxford: Clarendon Press).

GAUR, ALBERTINE, 1984. A History of Writing (London: The British Library).

Getty, Paul, 2002. The Metre of 'Beowulf': A Constraint-Based Approach (Berlin: and New York: Mouton de Gruyter)

GIBB, HAMILTON A. R., 1963. Arabic Literature, 2nd ed. (Oxford: Clarendon Press).

GIEGERICH, HEINZ J., 1980. 'On Stress-timing in English Phonology', Lingua, 51: $187-221$.

-, 1985. Metrical Phonology and Phonological Structure: German and English (Cambridge: Cambridge UP).

HALL, ROBERT A., 1965. 'Old Spanish Stress-Timed Verse and the Germanic Superstratum', Romance Philology, 19 (1965-66): 227-34

HALLE, MORRIS, 1997. 'On Stress and Accent in Indo-European', Language, 73: 275-313.

HAMER, RICHARD, ed. \& tr., 1970. A Choice of Anglo-Saxon Verse (London: Faber and Faber).

HAMMOND, PAUL, 1997. 'Optimality Theory and Prosody', in Archangeli and Langendoen 1997: 33-58. 
HANSON, KRISTIN, \& PAUL KIPARSKY, 1996. 'A Parametric Theory of Poetic Meter', Language, 72: 287-335.

HAYES, BRUCE, 1989. 'The Prosodic Hierarchy in Poetic Meter', in Phonetics and Phonology, I, Rhythm and Meter, ed. Paul Kiparsky \& Gilbert Youmans (San Diego: Academic Press), pp. 201-60.

_, 1995. Metrical Stress Theory: Principles and Case Studies (Chicago: Chicago UP).

HENRIQUEZ UREÑA, PEDRO, 1933. La versificación irregular en la poesía castellana, 2nd ed., Revista de Filología Española, anejo 4 (Madrid: Centro de Estudios Hispánicos).

HEUSLER, ANDREAS, 1891. 'Zur Metrik des altsächsischen und hochdeutschen Alliterations-verses', Germania, 36: 139-79 \& 279-307.

HILLS, E. C., 1925. 'Irregular Epic Metres: A Comparative Study of the Poem of the Cid and Certain Anglo-Norman, Franco-Italian and Venetian Epic Poems', in Homenaje to Menéndez Pidal, I (Madrid: Hernando), pp. 759-77.

HOGG, RICHARD M., \& CHRISTOPHER B. MCCULLY, 1987. Metrical Phonology: A Course Book (Cambridge: Cambridge UP).

HURFORD, JAMES R., 1987. Language and Number: The Emergence of a Cognitive System (Oxford: Blackwell).

JAKOBSON, ROMAN, 1960. 'Linguistics and Poetics', in Style in Language, ed. Thomas A. Sebeok (Boston: MIT Press), pp. 350-77.

LEWIS, C. S., 1938. 'The Fifteenth-Century Heroic Line', Essays and Studies, 24: 28-41.

LIBERMAN, MARK Y., \& ALAN PRINCE, 1977. 'On Stress and Linguistic Rhythm', Linguistic Inquiry, 8: 249-336.

LORD, ALBERT B., 1960. The Singer of Tales, Harvard Studies in Comparative Literature, 24 (Cambridge, MA: Harvard UP).

LUECKE, JANE-MARIE, 1978. Measuring Old English Rhythm: An Application of the Principles of Gregorian Chant to the Meter of 'Beowulf', Literary Monographs, 9 (Madison: University of Wisconsin Press).

MACRI, ORESTE, 1979. Ensayo de métrica sintagmática (Madrid: Gredos).

MEILLET. P. J. ANTOINE, 1923. Les Origines indo-européennes des mètres grecs (Paris: Presses Universitaires de France).

MILÁ Y FONTANALS, MANUEL, 1893. 'De la poesía popular gallega', in his Obras completas, v, (Barcelona: Alvaro Verdaguer), pp. 363-93.

MILLER, GEORGE A., 1956. 'The Magical Number Seven Plus or Minus Two', Psychological Review, 63: 81-97.

NAVARRO (TOMÁS), TOMÁS, 1974. Métrica española, $4^{\text {th }}$ ed. revised (Madrid: Guadarrama).

PARKINSON, STEPHEN, in press. 'Concurrent Patterns of Verse Design in the Galician-Portuguese Lyric', in Proceedings of the Twelfth Colloquium, ed. Alan Deyermond \& Jane Whetnall, PMHRS, 35, (London QMW), to appear.

POPE, JOHN C., 1942. The Rhythms of Beowulf: An Interpretation of the Normal and Hypermetric Verse-Forms in Old English Poetry (New Haven: Yale UP); revised ed. 1966.

-, ed., 1967-68. The Homilies of Alfric: A Supplementary Collection, 2 vols, EETS os 259\& 260 (London: Oxford UP).

PREMINGER, ALEX, \& T. V. F. BROGAN, WITH FRANK J. WARNKE, O.B. HARDISON, JR, \& EARL MINER, ed., 1993. The New Princeton Encyclopedia 
of Poetry and Poetics (Princeton NJ: Princeton UP).

PURCZINSKY, JULIUS, 1965. 'Germanic Influence in the Sainte Eulalia', Romance Philology, 19 (1965-66): 271-75.

QUILIS, ANTONIO, 1971. 'Caracterización fonética del acento español', Travaux de Linguistique et de Littérature, 9: 53-72.

ROACH, PETER, 1982. 'On the Distinction between "Stress-timed" and "Syllable-timed" Languages', in Linguistic Controversies: Essays in Honour of F.R. Palmer, ed. David Crystal (London: Edward Arnold), pp. 73-79.

RUSSOM, GEOFFREY, 1987. Old English Meter and Linguistic Theory (Cambridge: Cambridge UP).

-, 1998. 'Beowulf' and Old Germanic Metre (Cambridge: Cambridge UP).

SCRAGG, DONALD, ed., 1991.The Battle of Maldon, AD 991 (Oxford: Blackwell and the Manchester Centre for Anglo-Saxon Studies).

SIEVERS, EDUARD, 1885. 'Zur Rhythmik des germanischen Alliterationsverses', Pauls und Braunes Beiträge, 10: 209-314 \& 451-545.

SKEAT, W. W., 1898. 'On the Scansion of English Poetry', Transactions of the Philological Society, 484-503.

STOCKWELL, ROBERT, \& DONKA MINKOVA, 1997. 'The Prosody of Beowulf', in $A$ 'Beowulf' Handbook, ed. Robert Bjork \& John D. Niles (Lincoln: Nebraska UP), pp. 55-83.

TOLEDO, GUILLERMO ANDRÉS, 1988. El ritmo en español: estudio fonético con base conputacional, Biblioteca Románica Hispánica, 2.361 (Madrid: Gredos).

WACKERNAGEL, WILHELM, 1879. Geshichte der deutschen Literatur, $2^{\text {nd }}$ ed., 2 vols (Basel: Druck und Verlag der Schweighauserischen Buchhandlung).

WEST, M. L., 1973. 'Indo-European Metre', Glotta, 51: 161-87.

WRENN, C. L., \& W. F. BOLTON, ed., 1988. 'Beowulf' with the 'Finnesburg Fragment', $4^{\text {th }}$ ed. revised (Exeter: Univ. of Exeter). 